\title{
Некоторые аспекты политики стран Балтии В сфере морского недропользования (на примере спора между Латвией и Литвой о делиминации морской границы)
}

\section{Овлащенко А.B.*}

Почти полвека назад в предисловии к книге Д. О'Коннела профессор Ю.Г. Барсегов писал: «Передача территории от одного национального общества к другому вызывает трудные и сложные юридические проблемы. Такие передачи были часты в современной истории и нередко радикальны по своему масштабу и последствиям... Эти территориальные передвижки оказывают неожиданное и зачастую серьезное влияние на международные отношения. Вопрос о границах нового государства нередко затрагивает интересы не только государства-предшественника и государства-преемника, но и соседние государства»' .

Получение независимости республиками СССР повлекло за собой обострение геополитической ситуации на постсоветском пространстве. Вопросы делимитации морских границ (государственных и юрисдикционных) стали одними из сложнейших во взаимоотношениях новообразованных государств. Так, после получения независимости в начале 90-х гг. XX в. у Латвийской Республики возник целый ряд территориальных проблем, касающихся, в частности, делимитации морских границ с соседними государствами - Эстонией и Литвой.

Именно ко времени существования СССР относятся в большинстве своем договоры о делимитации морских границ. Тем не менее проблемы, связанные с разграничением морских границ между странами Балтии, возникли раньше. В 1921 г. для урегулирования пограничных вопросов между Латвией и Литвой были образованы согласительные комиссии двух государств, которые определили границу, примерно совпадающую с бывшей границей Курляндской губернии Российской Империи. Морской границей между сопредельными государствами стала прямая линия, являющаяся продолжением сухопутной границы

- Овлащенко Александр Владимирович - магистр, лектор Балтийского Русского института (Рига).

' О'Коннел Д. Правопреемство государств. М.: Издательство иностранной литературы, 1957. С. 7. 
в сторону моря. Морская граница между Латвией и Литвой, установленная в начале 20-х гг. XX в., не вызывала никаких взаимных претензий вплоть до начала 90-х годов.

Договор о восстановлении государственной границы между Латвийской Республикой и Литовской Республикой, заключенный 29 июня 1993 года, с приложением - Инструкцией о создании смешанной комиссии по восстановлению государственной границы, предусматривал, что часть государственной границы, которая представляет собой морскую границу, должен определять отдельный договор. Работу сторон над созданием и заключением этого договора затрудняло обсуждение вопросов о разведке, исследовании и добыче углеводородов в Балтийском море. На ближайшую перспективу такая деятельность и для Латвии, и для Литвы являлась реальной возможностью по привлечению в экономику средств западных нефтяных компаний. В свою очередь, установление латвийско-литовской морской границы, являлось предварительным условием привлечения иностранных инвесторов к разведке, исследованию и добыче морских углеводородов.

Геологические исследования, проведенные еше во времена $\mathrm{CCCP}^{2}$, показали, что потенциальные геологические ресурсы нефти на сухопутной территории и в морской среде (их поиском в 1975-1985 гг. занималась в числе прочих польско-немецко-советская фирма Petrobaltic) в пределах юрисдикции Латвийской Республики (тогда - Латвийской ССР) могут составлять около 130-150 млн т, в том числе получаемые ресурсы - около 25-42 млн т. Аналогичные показатели в Литве составляли соответственно 140 и 20-60 млн тонн. Латвийская нефть, в советское время полученная из скважины Е 6, была изучена в Институте морской геологии и геофизики. Оказалось, что по составу она близка нефти марки Brent, добываемой в Северном море. Согласно нынешним оценкам, Латвия в пределах своей юрисдикции (в Балтийском море) располагает примерно 250 млн баррелей нефти.

2 О перспективности Балтийского моря на нефтегазоносность, см.: Люткевич Е. М. Нефтегазоносность Прибалтики. Вильнюс: Минтис, 1965. Люткевич Е.М. История поисков нефти в Прибалтике и ее уроки / В сб.: Нефтепоисковые критерии Прибалтикн и методы их изучения. Вильнюс: Минтис, 1970. С. 7-17. Кроме того, в Балтийском море прогнозировалось наличие россылей титана, золота, магнетита, янтаря, железомарганцевых конкреций. (См.: Варенцов И.М., Блажчииин А.И. Формирование железо-марганцевых конкреций и корковидных образований на дне Балтийского моря / Конкреции и конкреционный анализ. Л., 1970. С. 102-104). 
Завладев после выхода из СССР материалами исследований, Латвия неоднократно получала претензии от Литвы. Они были вызваны нежеланием латвийской стороны распоряжаться информацией в интеpecax этих двух стран. В 1995 г. Латвией и Литвой были сформированы рабочие группы, основной задачей которых было достижение компромиссного решения путем переговоров. По результатам переговоров планировалось заключение двух договоров - о делимитаций морской границы между двумя странами и о «зоне общих интересов». В мае 1995 г. главы государств и правительств подписали в литовском городе Майшагола меморандум, согласно которому было провозглашено, что стороны будут руководствоваться положениями Конвенции о территориальном море и прилежащей зоне 1958 г. Переговоры, прошедшие в сентябре 1996 г, закончились безрезультатно из-за непоколебимых позиций сторон. Незадолго до этого в Латвии был принят закон «О недрах», в котором было определено, что углеводороды (непереработанная нефть (сырая нефть), природный газ и газовые конденсаты) являются полезными ископаемыми государственного значения ${ }^{3}$.

. Вскоре правительством Латвии была создана группа экспертов по вопросам освоения морских углеводородов. Экспертная группа разрабатывала поправки к законам, необходимые для того, чтобы начать разведку, исследование и добычу нефти в территориальном море Латвии. Затем эта группа была расформирована. Вместо нее при Агентстве развития создали новую структуру - Центр нефтяных ресурсов (занимался этими вопросами и Отдел нефтегазовой промышленности департамента энергетики при Министерстве экономики Латвийской Республики). В 1997 г. в состав латвийской рабочей группы на переговорах с Литвой вошли уже не только сотрудники Министерства иностранных дел Латвии, но и представители Государственной геологической службы, Государственной инспекции среды, Академии наук Латвии и Латвийского университета.

Что же касается Литвы, то в этом государстве практически отсутствовала законодательная база по морской нефтедобыче. Это весьма

${ }^{3} O$ nедрах. Закон, принямый Сеймом 2 мая 1996 года и обнародованный Президентои государства 21 иая 1996 года. В редакции закона от 16 декабря 2004 г. иместся «Информативная ссылка на директиву Европейского Союза», где указано: «В Закон включены правовые нормы, вытекающие из Директивы Европейского Парламента и Совета от 30 мая 1994 года 94/22/ЕК о правилах предоставления и использования разрешений на разведку, исследование и добычу углеводородов». 
негативно сказывалось на всей политике Литовской Республики в сфере морского недропользования, поскольку совершенно понятно, что «благоприятные по содержанию, ясные по форме, стабильные во времени законодательные условия сами по себе усиливают инвестиционную привлекательность экономических проектов в конкретном морском районе», а «иная законодательная среда отталкивает инвесторов» ${ }^{4}$. Тем более ни в коей мере не может привлекать инвесторов отсутствие этой самой среды.

Оценивая ситуацию, необходимо отметить, что вопрос о морской границе обострился после приобретения у Латвии разрешений (лицензий) на использование недр американской компанией AMOCO Latvia Petroleum Company (AMOCO) и шведской - Olteprospektering $A G$ $(O P A B)$. В связи с тем, что Латвия, все в том же 1995 г. подписала Протокол намерений о разведке морских углеводородов и подготовила договор с фирмой $A M O C O$, возник спор с Литовской Республикой, касающийся делимитации морской границы. Этот спор, едва не привел к разрыву дипломатических отношений между двумя странами. Литва отозвала своего посла из Латвии, через некоторое время Латвия намеревалась передать спор на рассмотрение Международного Суда $\mathrm{OOH}^{5}$.

Литва потребовала отмены Протокола (эти требования соответствовали положениям совместного латвийско-литовского меморандума, где подчеркивалась недопустимость ведения переговоров с третьими странами по вопросам нефтяных ресурсов Балтийского моря), полагая при этом, что до делимитации морской границы участок недр, где должна была вестись разведка морских углеводородов, является спорной територией.

В 1997 г. один из подрядчиков - компания $A M O C O$ - расторгла договор. Компания $O P A B$, формально владея разрешением (лицензией) на использование недр, практическую деятельность прекратила,

${ }^{4}$ Вылегжанин A.Н., Калаикарян Р.А. К учету международно-правового опыта в работе по кодификации морского законодательства России // Государство и право. 2005. № 3. С. 54.

${ }^{s}$ Как и раньше, конкурентная борьба нефтяных компаний, их стремление добиться выгодных условий на разведку и разработку нефтяных месторождений служат источником территориальных споров, политических конфликтов и трений между государствами. Так, проникновение монополий США к месторождениям нефти в устье реки Ла-Плата привело в 70-е гr. XX в. к дипломатической войне между Аргентиной и Уругваем. 
поскольку было обнаружено крупное месторождение углеводородов в Северном море. В июле 1999 г. главы правительств Латвии и Литвы подписали договор о делимитации морской границы. Договор предусматривал, что в случае обнаружения месторождения полезных ископаемых, пересекающих морскую границу, ни одна из сторон не вправе начинать разработку этого месторождения на своей территории до тех пор, пока не будет достигнута договоренность со второй стороной о разделе расходов и доходов, связанньх с добычей полезньх ископаемых.

Комиссия по народному хозяйству, среде, аграрной и региональной политике Сэйма Латвии не поддержала заключенный с Литвой договор. Последующий длительный отказ Сэйма ратифицировать его наглядно свидетельствовал о целом ряде не решенных этим договором проблем. Президент Латвии В. Вике-Фрейберга, наоборот, настаивала на скорейшей ратификации договора, поскольку точное определение морской границы являлось обязательным условием для вступления Латвии (и Литвы) в НАТО и Европейский Союз.

В 2001 г. в Лондоне состоялась презентация разрешений (лицензий) на использование недр - разведку, исследование и добычу морских углеводородов, закончившаяся для Латвии практически безрезультатно. В дальнейшем объявленный правительством Латвии конкурс на проведение поисковых работ и добычу нефти завершился вручением (в апреле 2002 г.) лицензии американо-норвежской компании TGSNopec Geophysical ASA (TGS Nopec) - единственной компании, изъявившей готовность принять участие в конкурсе. Лицензия, которую купила компания TGS Nopec, давала право на проведение только разведочных работ (но не на добычу нефти). Для разведки, исследования и последующей добычи нефти существовали три другие разрешения на использование недр стоимостью 75 тысяч латов каждое. Они давали право проводить разведку и добычу углеводородов на трех лицензионных площадях Балтийского моря площадью 1143, 765 и 767 кв. км. Срок лицензий - 30 лет, с условием, что разведывательные работы продлятся не более пяти лет.

Лицензии на разведку, исследование и добычу углеводородов предполагали, что доля государства составит 10\% (ими должно было управлять Латвийское агентство развития). Обладатель лицензии должен был выплатить подоходный налог с предприятия (25\%) и государственную пошлину на добычу нефти (royalty), размер которой зависел от объемов добычи (при добыче в 10 тысяч баррелей в сутки - 2\%, 
более 80 тысяч баррелей - 12\%). Доходы государства от добычи нефти могли составлять от 37 до $47 \%$.

Конечно, перед нефтедобывающими компаниями возникал вопрос об экономической целесообразности добычи морских углеводородов. В Латвии был принят Закон об инвестициях, в одной из статей которого было оговорено, что, если объем инвестиций превышает 10 млн долларов, то скидка на подоходный налог с предприятий может составлять до $40 \%$. Это означало, что доход государства от добычи нефти может сократиться на 10\%, потому что вложения нефтедобывающих компаний явно превысят 10 млн долларов (учитывая, что только одна скважина может обойтись в 6-8 млн).

К положительным моментам нефтедобывающие компании относили то, что латвийская нефть залегает в кембрийских и ордовикской породах, расположенных на глубине 1,3-2 км; встречаются скопления нефти и в более высоких породах - девонской и силурийской. Немаловажными факторами являются и близкое расположение нефтеперерабатывающих заводов, а также потенциальных потребителей (к ним в Латвии сегодня в первую очередь относят Финляндию и Швецию). Учитывая все эти аспекты, все та же экспертная группа в свое время составила пессимистический и оптимистический прогнозы морской добычи углеводородов. Пессимистический основывался на том, что при минимальных запасах нефти доход государства составил бы 2-3 млрд долларов. Оптимистический прогноз давал цифру 6 млрд долларов.

Естественно, вставал вопрос и о том, как выгоднее использовать добытую нефть. Рассматривалась возможность строительства небольшого нефтехимического завода в Вентспилсе или Лиепае с целью глубокой переработки нефти для производства пластмасс, смазочных материалов и ингредиентов для изготовления парфюмерной продукции. И все-таки лучшим вариантом признавалось получение процента прибыли от нефтедобываюших компаний. Имелись планы и по созданию национальной нефтедобывающей компании.

Как видно, геополитические изменения которые произошли в регионе Балтийского моря, в частности появление на его берегах государств Латвия, Литва и Эстония, выявили проблему делимитации морских границ между этими странами. Несмотря на внешне технический характер, делимитация морских границ связана со многими сложностями и непосредственно зависит от геополитических, внутриполити- 
ческих, юридических и экономических вопросов. В данном случае международно-правовая практика в очередной раз подтвердила, что наличие углеводородов значительно осложняет ход делимитации. В то же время важным моментом для понимания обстановки, сложившейся вокруг стран Балтии (по крайней мере в нынешних условиях), является преобладание геополитических и политических факторов над экономическими (и в этом ситуация весьма сходна с той, которая сложилась сегодня в Каспийском регионе).

Регион Балтийского моря имеет огромное значение для всей Европы, прежде всего с точки зрения обеспечения европейской безопасности. Возникновение напряженности в этом регионе оказывает непосредственное влияние на военно-политическую обстановку в общеевропейском масштабе. Можно ожидать, что, несмотря на рост интеграционных процессов, дальнейшая интеграция на политическом уровне будет иметь определенные сложности, которые обусловлены различными интересами государств - членов ЕС, включая их интересы и в сфере морского недропользования. Все это обусловливает необходимость дальнейшего изучения проблем правового регулирования морского недропользования, соответствующих изменений в законодательстве о недрах с последуюшим конечным обобщением тенденций развития морской политики этих государств.

В настоящее время атлантическое региональное направление национальной морской политики Российской Федерации характеризуется «резким сокрашением возможностей» по осушествлению государством своей морской деятельности. Поэтому основу национальной морской политики на данном направлении составляет решение долгосрочных задач и на Балтийском море. Несмотря на то, что на Балтийское море приходится лишь менее $1 \%$ ресурсов углеводородов российского шельфа (около 85\% расположены в арктических морях; на шельф дальневосточных морей Российской Федерации приходится около $14 \%$ запасов нефти и газа), в июле 2004 г. была добыта первая нефть с месторождения Кравцовское на шельфе Балтийского моря. В России появился новый добывающий регион.

Весьма важным представляется, что в число долгосрочных задач национальной морской политики входит «создание условий для стабильного экономического сотрудничества со странами Балтийского региона, рационального совместного использования морских природных ресурсов, придание мерам доверия всеобъемлющего характера 
во всех областях морской деятельности», а также «разрешение вопросов, связанных с разграничением морских пространств и континентального шельфа между Российской Федерацией, прилежашими и противолежащими государствами» ${ }^{6}$.

'Морская доктрина Российской Федерации на период до 2020 2. Утверждена Презиdeнmoи РФ 27 июля 2001 zoda (http://www.sops.ru/rus/research/doctrina.asp). 